\title{
The Goldwater Rule from the Perspective of Phenomenological Psychopathology
}

\author{
Seon-Cheol Park, MD, PhD $\bowtie$ \\ Department of Psychiatry, Inje University College of Medicine and Haeundae Paik Hospital, Busan, Republic of Korea
}

In the United States presidential election of 1964, Barry Goldwater competed with Lyndon Johnson, and Fact Magazine presented 1,189 psychiatrists' suggestions for Goldwater's psychological unfitness to be president. Barry Goldwater sued Ralph Ginzburg, the editor of Fact Magazine, for defamation and won $\$ 75,000$ (about $\$ 592,000$ today) in damages. ${ }^{1-6}$ Thereafter, according to the medical ethical principles of the American Psychiatric Association (APA), it is considered unethical for psychiatrists to give their professional opinion about public figures who have not been evaluated personally and who do not agree with public opinion about their mental health. ${ }^{7}$ Further, consistent with the ethical principles of the APA, the American Psychological Association's ethical principles recommend taking strict precautions about psychologists' media presentations. ${ }^{8}$ Somewhat inconsistent with the ethical principles of the APA, the American Psychoanalytic Association (APsaA) partly permits psychoanalysts to offer psychoanalytic insights to help the public comprehend a wide range of political, artistic, cultural, historical, economic, and other phenomena. Despite this permission, psychoanalysts have been requested to maintain "extreme caution" when making statements to the mass media about public figures, and the limitations of psychoanalytic inferences about individuals who have not been interviewed in depth has been noted. ${ }^{9}$ As shown in Table 1, according to the ethical principles of these mental health professional societies, professional comments about public figures via mass media are commonly regarded as acts

Received: January 15, 2018 Accepted: January 25, 2018

Available online: February 22, 2018

$\triangle$ Correspondence: Seon-Cheol Park, MD, PhD

Department of Psychiatry, Inje University College of Medicine and Haeundae Paik Hospital, 875 Haeun-daero, Haeundae-gu, Busan 48108, Republic of Korea Tel: +82-51-797-3300, Fax: +82-51-797-0298

E-mail: cogito-ergo-sum@hanmail.net

(a) This is an Open Access article distributed under the terms of the Creative Commons Attribution Non-Commercial License (http://creativecommons.org/licenses/by$\mathrm{nc} / 4.0$ ) which permits unrestricted non-commercial use, distribution, and reproduction in any medium, provided the original work is properly cited. that are inconsistent with journalism ethics or should be carried out with "extreme precaution."

An united theory of psychiatric ethics in the absence of interview and consent remains arbitrary and ambiguous beyond the physician-patient relationship. For example, deceased public figures of historical interest are an exception in the Goldwater rule. ${ }^{1-6}$ Based on the duty to warn (so-called Tarasoff rule) that emerged from the California Supreme Court's decision in $1976,{ }^{10} 27$ psychiatrists and mental health professionals have speculated Donald Trump's (current president of the United States) core problems and their potential effects in the recently published book The Dangerous Case of Donald Trump. Although the book's publication has been justified because of the predominance of the "duty to warn" over the Goldwater rule in the case of Donald Trump, such sharing of professional opinions about public figures in the absence of interview data inevitably includes epistemological and scientific limitations. ${ }^{11}$

Karl Jaspers introduced Husserl's phenomenological concepts into psychopathology. In the phenomenological perspective, intentionality is regarded as the essential characteristics of consciousness, and the essence of subjective experience can be approached with given intuition by epoché (phenomenological reduction). ${ }^{12}$ In accordance with the phenomenological perspective, descriptive psychopathology can be defined as the conceptual network connecting the psychiatrist, patient, and mental symptoms. ${ }^{13}$ In other words, the identification of mental symptoms can be established only in terms of the psychiatrist-patient relationship, and psychiatric diagnosis can be regarded as not a checklist but an interactive and embodied social cognitive process. Phenomenological approaches are needed to understand a patient's subjective experience in the era of DSM-5. ${ }^{14}$ Thus, it is speculated that the lack of an interactive relationship between a psychiatrist and patient can be grounds for disqualification in terms of making a 
Table 1. Goldwater rule-related ethical principles or guidelines of the American Psychiatric Association (APA), American Psychological Association, and American Psychoanalytic Association (APsaA)

\begin{tabular}{|c|c|}
\hline Academic societies & Goldwater rule-related ethical principles or guidelines \\
\hline $\begin{array}{l}\text { American Psychiatric } \\
\text { Association (APA) }\end{array}$ & $\begin{array}{l}\text { "On occasion psychiatrists are asked for an opinion about an individual who is in the light of public attention or } \\
\text { who has disclosed information about himself/herself through public media. In such circumstances, a psychia- } \\
\text { trist may share with the public his or her expertise about psychiatric issues in general. However, it is unethical } \\
\text { for a psychiatrist to offer a professional opinion unless he or she has conducted an examination and has been } \\
\text { granted proper authorization for such a statement." }\end{array}$ \\
\hline $\begin{array}{l}\text { American Psychological } \\
\text { Association }\end{array}$ & $\begin{array}{l}\text { "When psychologists provide public advice or comment via print, Internet, or other electronic transmission, } \\
\text { they take precautions to ensure that statements 1) are based on their professional knowledge, training, or ex- } \\
\text { perience in accord with appropriate psychological literature and practice; 2) are otherwise consistent with this } \\
\text { Ethics Code; and 3) do not indicate that a professional relationship has been established with the recipient." }\end{array}$ \\
\hline $\begin{array}{l}\text { American Psychoanalytic } \\
\text { Association (APsaA) }\end{array}$ & $\begin{array}{l}\text { "Avoid thinly veiled, disingenuous diagnostic interpretations of public figures, such as "I can't say anything about } \\
\text { Senator Smith because I haven't interviewed him, but people who behave like him generally have a narcis- } \\
\text { sistic personality disorder". Obviously, you are offering a diagnosis of Senator Smith. Communicate a range of } \\
\text { possible psychoanalytic and other explanations for the behavior in question, with the clear statement that you } \\
\text { don't know which if any of these is true about the particular public figure. Attempt to turn the conversation } \\
\text { to an area where you can make definitive statements, such as the public reaction to the surprising behavior. } \\
\text { Never make a definitive statement about the personal psychodynamics or diagnosis of a public figure." }\end{array}$ \\
\hline
\end{tabular}

provisional psychiatric diagnosis in the strict sense of phenomenological psychopathology. Moreover, the Goldwater rule may be partly supported by the phenomenological perspective.

"Offering a definite medical diagnosis without a thorough personal evaluation and the consent of the person being assessed can easily degenerate into speculation and name-calling, which discredits the clinician making the less than optimally founded diagnosis" (Leonard L. Glass, The Dangerous Case of Donald Trump, 2017). ${ }^{11}$

\section{REFERENCES}

1. Kroll J, Pouncey C. The ethics of APA's Goldwater rule. J Am Acad Psychiatry Law 2017;44:226-235.

2. Martin-Joy J. Introduction to the special section on the Goldwater rule. J Am Acad Psychiatry Law 2017;45:223-227.

3. Appelbaum PS. Reflections on the Goldwater rule. J Am Acad Psychiatry Law 2017;45:228-232.

4. Martin-Joy J. Interpreting the Goldwater rule. J Am Acad Psychiatry Law 2017;45:233-240.

5. Levine MA. Journalism ethics and the Goldwater rule in a "post-truth" media world. J Am Acad Psychiatry Law 2017;45:241-248.

6. Jindal RD. The educational value in the Goldwater rule. Acad Psychiatry 2017 [Epub ahead of print]

7. American Psychiatric Association. Principles of Medical Ethics with Annotations 2010 Edition, Section 7. American Psychiatric Associa- tion. Available at: http://www.psych.org/MainMenu/PsychiatricPractice/Ethics/ResourcesStandards/Principles-of-Medical-Ethics2010-Edition.aspx?FT=.pdf. Accessed January 11, 2018.

8. American Psychological Association. Ethical Principles of Psychologists and Code of Conduct, standard 5.04 and 9.01. American Psychological Association. Available at http://www.apa.org/ethics/code/ethics-code-2017.pdf. Accessed January 11, 2018.

9. American Psychoanalytic Association. Position Statement Regarding Psychoanalysts' Providing Commentary on Public Figures. American Psychoanalytic Association]. Available at: https://www.apsa.org/sites/ default/files/2012\%20Position\%20Statement\%20Regarding\%20Psychoanalysts.pdf. Accessed January 11, 2018.

10. Transcript of the Yale Conference. Available at https://us.macmillan. com/static/duty-to-warn-conference-transcript.pdf. Accessed January 11, 2018.

11. Glass LL. Should Psychiatrists Refrain from Commenting on Trump's Psychology? In: Lee B, Editor. The Dangerous Case of Donald Trump. New York: St. Martin’s Press, 2017, p.151-159.

12. Spiegelberg H. Karl Jaspers (1883-1969): Introducing Phenomenology into Psychopathology. In: Spiegelberg H, Editor. Phenomenology in Psychology and Psychiatry. Evanston: Northwestern University Press, 1972, p.173-191.

13. Berrios GE. The History of Mental Symptoms. Descriptive Psychopathology Since the 19th Century. Cambridge: Cambridge University Press; 1996.

14. Mishara AL, Schwartz MA. What Does Phenomenology Contribute to the Debate about DSM-5. In: Paris J, Phillips J, Editors. Making the DSM-5: Concepts and Controversies. New York: Springer, 2013, p.125142. 